\title{
Isokari Francis Ololo, The Shepherd Leader: The Unexplored Leadership Style, North Charleston
}

\author{
John Olushola Magbadelo* \\ Director (Research \& Studies), Centre for African, Nigeria
}

Submission: July 24, 2019; Published: August 07, 2019

"Corresponding author: John Olushola Magbadelo, Director (Research \& Studies), Centre for African \&Asian Studies, P.0. Box 6563 Garki Area 10 Post Office, Abuja, Nigeria

Keywords: Shepherd leader; North charleston; Leadership; Book of Psalms

\section{Opinion}

Leadership is a timeless subject and will remain so in the affairs of humans till, perhaps, eternity emerges. The currency of leadership in social discourses is testamentary to its nebulous nature, evident in the absence of consensus on what the concept means. There have been several publications on leadership from diverse perspectives depending, of course, on the values of the different theorists. The more theories on leadership that are churned out by the theorists, the more confusing and elusive the concept becomes. It is, however, possible to classify all existing literature on leadership into two broad categories, namely, those that portray leadership as an art that can be learnt, and those that see it as an in-born or innate gifting. It is on either of these two perspectives that most of the theories on leadership hinge.

Dr. Ololo's book, The Shepherd Leader... presents a unique dimension to the conundrum that leadership as a concept currently evokes. Leadership from the theological and biblical point of view as Ololo espouses, entails sacrificial devotion of the leader who he likens to a 'Shepherd' to the requirements of his followers, who are the' sheep'. The Davidic conception of Shepherd hood as reflected in the twenty-third chapter of the book of Psalms in the Bible constitutes the pivot of Ololo's treatise on Shepherd leadership. The different attributes of the shepherd which are discernible in his relationship with his sheep are chronicled in the eight chapters of this book. In chapter one, the author gives an overview of the qualities and indeed the emotional intelligence of the shepherd leader, who he opines, exhibits all the six leadership styles identified by Daniel Goleman as affiliative, visionary, coachoriented, commanding, democratic, and pacesetter-oriented (pp. 1- 22).

Chapter Two explicates the diverse manifestations of shepherd leadership in Joseph's conduct in periods preceding his elevation as the Prime Minister of Egypt and during his actual reign as the
Prime Minister of that country, which the author situated within the context of the predilection of the shepherd to make provisions for his sheep. Joseph's deployment of divine wisdom in providing solution to Egypt's imminent problem of famine made Egypt to experience prosperity which" was applied to preserve life of the Egyptians and their neighbours" (p. 41)

Chapter Three examines how a shepherd leader ensures the safety and protection of the peace of his sheep in comparison with the secular strategies often utilized by other leadership styles. The shepherd leader uses the rod to settle conflict with dissidents only "when it becomes extremely necessary, such as in emergency situations"(p. 65) Citing different instances and personalities in the Bible, the author identified the tools for conflict resolution which the shepherd leader uses to include attack, integrity and transparency, provision -focused, pro-obedience method, losewin attitude, wisdom-attuned, destruction, compassion, appeal to emotion, enlightened disobedience, analogy, the end-in-view method, and love, which he describes as the "chief tool of conflict negotiation and management"(p. 82).

The characteristics of parenting comprising among others, caring nature, philanthropy, placation, availability, enablement, empathy, participation, perspicacity, acuity, and alertness, which the author likens to that of a shepherd leader, are well-analyzed in chapter four of the book. The differences between profligate leadership and shepherd leadership are chronicled in this chapter. Whilst a profligate leaders distance God from their leadership and they focus on reward more than service; a shepherd leader is divinely inspired" through the proper and rigid doctrines and laws he subjects himself to and operates within" (p. 106).

Chapter Five is an exposition on the obligation of the shepherd leaders to heal and prevent their sheep from experiencing hurtful situations while depicting the hurtful leaders as the exact 
opposites. The author affirms that "shepherd leaders do not hurt others. Their rod is for correction of their flock" (p. 130). In the case of the hurtful leaders, he observes that they "infringe upon the peace of their countries as well as upon the lives of their citizenry" (p. 131). He condemned leaders who had stayed for periods above twenty years in office despite the opposition of their citizens to their long stay in office without any visible achievement (p. 130).

Chapter Six is an explicit comparison between 'leadership by endowment' and 'emasculated leadership' The author defines 'leadership by endowment' as "a leadership style built on trust, approval, and support both by the leader and the followers" (p. 141) An endowed leader is described as a leader that "is quick in bequeathing, conferring, and bestowing the endowments he is gifted with upon others" An emasculated leader is portrayed as a disempowered leader who lacks vision, power and influence to inspire his followers(p. 155). The author utilizes relevant biblical references and his personal encounters to explicate the different traits of the two variants of leadership while concluding that shepherd leaders are endowed leaders.

Chapter Seven is an elaboration on the use of the rod and the staff by the shepherd in relation to his sheep. The rod is depicted as a symbolic instrument for correction, punishment and for the retention of focus. The author asserts that "the shepherd leaders address the follies of their followers in a timely manner, and with the aim of making the guilty party come out better after the corrective action" (p. 169). The staff, he opines, symbolizes restoration which represents how the shepherd rests and refreshes to re-engage himself thereafter for his assignment. With good rest, he notes, the shepherd leader becomes more alert, energized, committed to responsibility, remain focused, and learn to choose his attitude (pp. 170-180).

Chapter Eight which concludes the book chronicles the differences between divinely inspired leaders and dumb leaders. According to the author, shepherd leaders are divinely attuned and inspired leaders, "because they seek the only wise God for intuition and discernment" (p. 188). Dumb leaders are portrayed as deceitful, wicked and devilish as they have pleasure in bringing the economies of their countries to "a disastrous predicament" ( $p$. 227). Obviously, this book is unique both in its focus and contents. It throws-up a new perspective on the concept of leadership which is anchored on its theological essence as reflected in the copious references to biblical citations by the author to affirm their applicability and relevance to governance challenges of the contemporary world which is bereft of good leadership in the mould of a shepherd leader.

The author has broached an important subject which would generate scholarly conversations on how certain key elements or principles of shepherd leadership can be replicated in the modern state structure with its secular posture. Should our political leaders be chosen through some spiritual selection procedure? How can we ensure that only those with some strong and unquestionable connection to divinity are democratically elected as political leaders in most of our secular countries? Do we have reference points of divinely inspired leadership or shepherd leadership in our contemporary world? These questions were not addressed by the author.

However, the core message of this book which Dr. Ololo has proven and validated in the several instances alluded to in the Bible, is that leadership that is divinely guided will be peopleoriented, and that our world would be a better place to live if our leaders have the heart of a shepherd. This book is well-written, and it is a valuable contribution to the theories of leadership, which should be read by all, regardless of religious affiliations because it communicates timeless wisdom on how to be a good and people-centered leader.

Parsons Simon, Marcinkiewicz Marek, Niu Jinzhong, Phelps Steve (2006) Everything You Wanted to Know about Double-auctions but were Afraid to (Bid or) Ask. working paper, Brooklyn College, CUNY, University of Liverpool, UK.

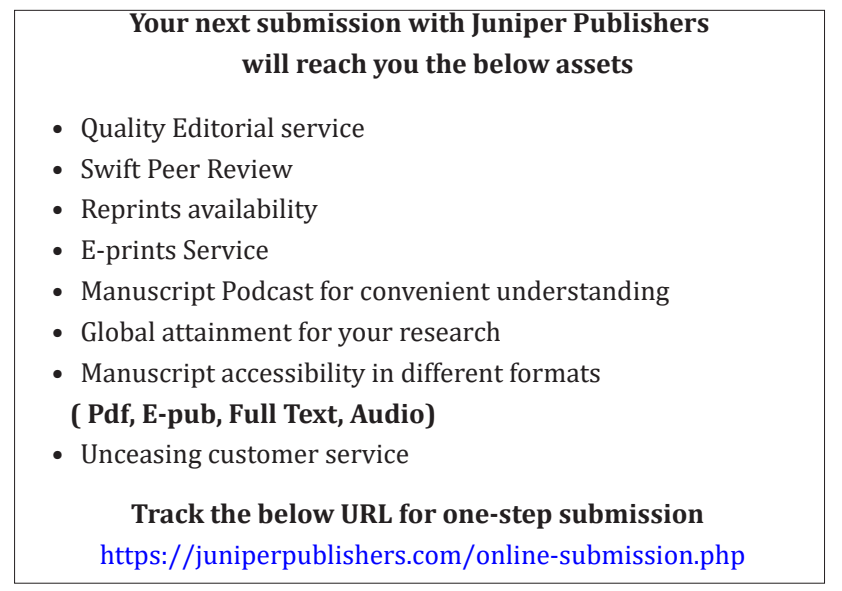

